\title{
EMULSION LIQUID MEMBRANE EXTRACTION OF Zr AND Hf IN ACID NITRIC USING EXTRACTANT TOPO
}

\author{
Kris Tri Basuki ${ }^{\star}$ and Sudibyo** \\ *Polytechnic Institute of Nuclear Technology - National Nuclear Energy Agency \\ Kampus STTN-BATAN JIn Babarsari KP 6101 YKBB, Yogyakarta 55281 \\ Email : kristri basuki@batan.go.id \\ ${ }^{* *}$ Center for Science and Technology Accelerator - National Nuclear Energy Agency \\ Jl. Babarsari Kotak Pos 6101 Ykbb, Yogyakarta 55281 \\ Diterima: 19-12-2016 \\ Diterima dalam bentuk revisi: 01-02-2017 \\ Disetujui: 06-02-2017
}

\begin{abstract}
ABSTRAK
EKSTRAKSI EMULSI MEMBRANE CAIR Zr dan Hf DALAM LARUTAN ASAM NITRAT DENGAN EKSTRAKTAN TOPO. Telah dilakukan ekstraksi larutan $\mathrm{Zr}$ yang mengandung $\mathrm{Hf}$ menggunakan extraktan TOPO. Sebagai fasa air digunakan larutan campuran $\mathrm{ZrO}\left(\mathrm{NO}_{3}\right)_{2}$ dan $\mathrm{HfO}\left(\mathrm{NO}_{3}\right)_{2}$ yang mengandung $\mathrm{Zr} 10 \mathrm{gr} / \mathrm{L}$ dan $\mathrm{Hf} 500 \mathrm{mg} / \mathrm{L}$, sedangkan ekstraktan atau fasa organik adalah TOPO dengan variasi konsentrasi yang diencerkan dengan kerosen. Emulgator Span-80 digunakan untuk membuat larutan membrane emulsi.Fasa internal yang digunakan adalah asam nitrat 3M dan fasa eksternal yang digunakan adalah asam fosfat $5 \mathrm{M}$. Parameter yang diteliti yaitu konsentrasi ekstraktan, kecepatan pengadukan, waktu pengadukan, dan perbandingan fasa internal serta fasa eksternal. Untuk analisis Zr dan Hf digunakan metode X-Ray Fluorescence (XRF). Dari hasil optimasi proses ekstraksi $\mathrm{Zr}$ dan Hf dengan membran emulsi menggunakan ekstraktan TOPO diperoleh kesimpulan sebagai berikut: waktu pembuatan fasa membran adalah dengan kecepatan pengadukan $8000 \mathrm{rpm}$, konsentrasi TOPO 5\% dalam kerosen, konsentrasi internal asam nitrat $3 \mathrm{M}$, konsentrasi asam fosfat $5 \mathrm{M}$, waktu ekstraksi pengadukan 10 menit dengan kecepatan pengadukan tetap $500 \mathrm{rpm}$, dan perbandingan fasa membran dan fasa eksternal 1 : 1. Pada kondisi ini diperoleh faktor pisah (FP) $\mathrm{Zr}-\mathrm{Hf}=17,39$.
\end{abstract}

Kata kunci: ekstraksi, TOPO, zirkonium, hafnium, kerosen, XRF, membrane emulsi.

\begin{abstract}
EMULSION LIQUID MEMBRANE EXTRACTION OF Zr AND Hf IN ACID NITRIC USING EXTRACTANT TOPO. Extraction solution of $\mathrm{Zr}$ that containing $\mathrm{Hf}$ using TOPO extraktant has been done. As the liquid phase, mixed solution of $\mathrm{ZrO}\left(\mathrm{NO}_{3}\right)_{2}$ and $\mathrm{HfO}\left(\mathrm{NO}_{3}\right)_{2}$ containing $\mathrm{Zr} 10$ $\mathrm{g} / \mathrm{L}$ and $\mathrm{Hf} 500 \mathrm{mg} / \mathrm{L}$ was used, whereas extractant or organic phase was TOPO with a variation of the concentration, that was diluted with kerosene. Emulsifier Span-80 was used to make emulsion of membrane liquid. Internal phase of membrane solution used was $3 \mathrm{M}$ nitric acid and the external phase used was phosphoric acid 5M. The studied parameters were extractant concentration, stirring speed, stirring time, and the ratio of internal and external phase. For the analysis of $\mathrm{Zr}$ and $\mathrm{Hf}$, the X-Ray Fluorescence (XRF) was used. From the optimation results of the extraction process of $\mathrm{Zr}$ and $\mathrm{Hf}$ with emulsion membran using TOPO extractants obtained the following conclusions: the manufacture of membrane phase used the stirring speed of 8000 $\mathrm{rpm}$, the concentration of TOPO $5 \%$ in kerosene, internal concentration of $3 \mathrm{M}$ nitric acid, phosphoric acid concentration $5 \mathrm{M}$, the extraction time stirring 10 minutes with fixed stirring speed $500 \mathrm{rpm}$, and the ratio of membrane and external phase was 1:1. This conditions acquired a separating factor (SF) $\mathrm{Zr}-\mathrm{Hf}=17.39$.
\end{abstract}

Keywords: extraction, TOPO, zirconium, hafnium, kerosene, XRF, Membrane Emulsion. 


\section{INTRODUCTION}

Purification of zirconium ( $\mathrm{Zr}$ ) from impurities is necessary because reactor structural material requires $\mathrm{Zr}$ with a very high purity (nuclear degrees). One of the impurities that must be removed is hafnium $(\mathrm{Hf})$, which has neutron absorption (102 barns) which absorbs neutrons that should be used to hold a chain nuclear reaction (1). As the material structure of the reactor, $\mathrm{Zr}$ metal has some superior characteristics, which are corrosion resistant against water and moisture, high melting teller, strong structure and look of the low absorption of neutrons (barn 0.2) $(2,3)$.

Zirconium and hafnium are elements located in group IV of the periodic table. These elements have chemical properties similar to the ability to form a compound or complex ions are also almost the same. This causes difficulty in separation. Nevertheless there is little difference that the "ionic volume" that play a role in the stability of the shape complexity. Zirconium has a larger volume atoms ( $\mathrm{Zr}=13.97$ cubic Angstroms, $\mathrm{Hf}=13.42$ cubic Angstroms) but $\mathrm{Hf}$ has a volume larger ions (radius of $\mathrm{Zr}^{+4}=0.74$ Angstroms and fingers $\mathrm{Hf}^{+4}=0.75$ Angstroms). $\mathrm{Zr}$ tendency to combine with other ions is greater than $\mathrm{Hf}$, so complex compound $\mathrm{Zr}$ is more stable than the complex compound $\mathrm{Hf}$.(1).

For the separation of $\mathrm{Zr}$ of $\mathrm{Hf}$ is used in various ways, each using tools, solvents and different systems. Some of the methods used for the separation of $\mathrm{Zr}$ and $\mathrm{Hf}$, include fractional crystallization (4), solvent extraction (5-9), ion exchange (10-13), extractive distillation in molten salts (14), chromatography (15) and sublimation (1618). Liquid-liquid extraction using a solvent can be used methyl iso-butyl ketone (MIBK) and tri-butyl phosphate (TBP), tri-octyl phosphine oxide (TOPO).

Separation of zirconium and hafnium in a liquid-liquid extraction process can be done by changing the metals into complex compounds soluble in the organic phase. The organic phase has a ligand group that can react selectively to one or more of the metallic elements present in the water phase. Separation of metal elements is due to differences in reactivity and the diffusivity of each metal element to the organic phase.

According to the Nernst distribution law, if the two are not mutually mixed solvents included solute that can be dissolved in the second solvent, there will be a division of solubility. Both solvents are generally organic solvents and water. In the mix, solute will be distributed by itself into the two solvents, after stirring, and then left there will be two separate phases. Comparison of solute concentration in the second solvent remains and is a constant at a constant temperature.

The constant is known as constant coefficients distribution. The distribution coefficient (DC) is expressed by the following formula (18):

$$
\mathrm{DC}=\mathrm{C}_{2} / \mathrm{C}_{1} \text { or } \mathrm{DC}=\mathrm{C}_{\mathrm{o}} / \mathrm{C}_{\mathrm{a}}
$$

with:

$\mathrm{C}_{1}$ or $\mathrm{C}_{\mathrm{a}}$ is the concentration of solute in the first solvent or aqueous solvent.

$\mathrm{C}_{2}$ or $\mathrm{C}_{0}$ is the concentration of solute in a second solvent or an organic solvent. 
This research aimed to study the extraction of $\mathrm{Zr}-\mathrm{Hf}$ using a mixture of TOPO extractant and diluent kerosene with membrane emulsion method. Kerosene was chosen because it can improve the efficiency of the separation of $\mathrm{Zr}$ and enlarge the ability of the extractant in forming a complex with Zr. Reaction extraction separation of $\mathrm{Zr}-\mathrm{Hf}$ written as follows (9):

$\mathrm{ZrO}_{2}{ }^{+}+4 \mathrm{NO}_{3}{ }^{-}+2 \mathrm{H}^{+}+2 \mathrm{TOPO} \leftrightarrow \mathrm{Zr}\left(\mathrm{NO}_{3}\right)_{4}$ $2 \mathrm{TOPO}+\mathrm{H}_{2} \mathrm{O}$

$\mathrm{HfO}_{2}{ }^{+}+4 \mathrm{NO}_{3}^{-}+2 \mathrm{H}^{+}+2 \mathrm{TOPO} \leftrightarrow \mathrm{Hf}$

$\left(\mathrm{NO}_{3}\right)_{4} 2 \mathrm{TOPO}+\mathrm{H}_{2} \mathrm{O}$

Membrane processes for separation of chemical species from a mixture are gaining in importance and are emerging as a viable alternative to conventional separation processes. The emulsion liquid membrane (ELM) technique was regarded as an emerging separation technology and was extensively examined for potential applications in such fields as hydrometallurgy, environmental engineering, biochemical engineering, pharmaceutical engineering, and food technology (19-21). Due to large throughput, fast reaction, and easy phase separation, the major method used in the rare earth element separation industry is solvent extraction with mixer settler. However, this traditional equipment has many drawbacks, such as: large equipment area occupation, high energy consumption, and large solvent holdup (22). To solve the problems, many types of methods and equipment are devised, such as hollow fiber contactor (23), impregnated polymer beads and resin (22-24), ionic liquid $(25,26)$, magnetic absorption ${ }^{[27]}$, and polymer sorbent (28), etc. Emulsion liquid membranes (ELM) separation technique $(19,28)$ has been regarded as an emerging technology with considerable potential for a variety of applications such as recovery and concentration of metal ions and biochemical products and the removal of pollutants from waste waters. ELMs exhibit several attractive features in comparison with solvent extraction. These include a large specific surface area for extraction, simultaneous extraction and re-extraction in a single stage, and the requirement only small quantities of an expensive carrier (3032). In view of all these advantages, the separation of metals by the ELM techniques has drawn considerable attention (29).

In the present work, Emulsion liquid membrane is investigated to select the suitable conditions for extraction of $\mathrm{Zr}-\mathrm{Hf}$ ions from acidic nitric solutions using TOPO as extractant. The effects of extractant and surfactant concentrations, mixing speed, concentration and type of stripping solution, phase ratio, treatment ratio, and nature of diluent on the extraction rate were studied. Under the optimum conditions, extraction of $\mathrm{Zr}-\mathrm{Hf}$ ions has been also studied for different feed mixture solution. Solvent extraction and stripping of $\mathrm{Zr}-\mathrm{Hf}$ ions were carried out in order to study the influence of the concentration of the aqueous solution, the concentration of TOPO, the equilibrium time on the extraction percent of $\mathrm{Zr}-\mathrm{Hf}$ ions and stripping percent of this metal ions from 
loaded organic phase by hydrochloric acid solut

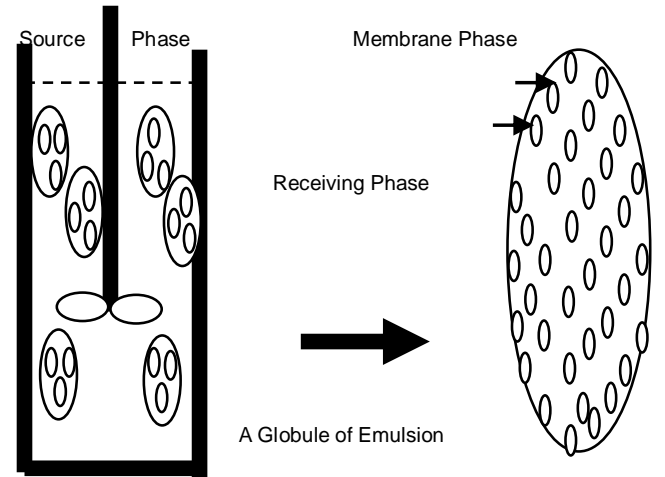

Figure 1: Configurations for Emulsion Unsupported (Kris Tri Basuki et al, Jurnal Urania, Vol 22 No 3 2016, 133-202)

Figure 1 shows possible configurations emulsion (unsupported), the configuration supported liquid membranes system.Globules is a granular of organic phase in the emulsion solution.

In General, liquid membranes can be held in porous structure or bounded on either side by two thin polymeric films. Emulsion (unsupported) liquid membranes are usually in the form of double emulsion drop. In a Water/Oil/Water (W/O/W) system, immiscible is the oil phase, separating the two aqueouse phases, while in an $\mathrm{O} / \mathrm{W} / \mathrm{O}$ system, the liquid membrane is the immiscible water phase which separates the wo oil phases (19).

Figure 2 showed a sequence of even in the preparation and operation for an $\mathrm{W} / \mathrm{O} / \mathrm{W}$ emulsion liquid membrane system. The emulsion system are usually prepared by forming an emulsion from two immiscible phase by vigorously stirring at $2000-10000$ rpm. Then emulsion disperse in continuous phase (external phase) by low speed agitation. The liquid membrane phase which is separates the encapsulated droplets in the emulsion form the external continuous phase. In general, the internal phase droplets are very small, having diameter of 1 $-10 \mu \mathrm{m}$, whereas the emulsion globules are usually about $0,1-2 \mathrm{~mm}$ in diameter. Surfactant and additives are normally included in the membrane. At the end of an extraction run, the emulsion and external phases can be separated, and reacted internal reagent phase can be recovered, if desired, by breaking the emulsion (19).

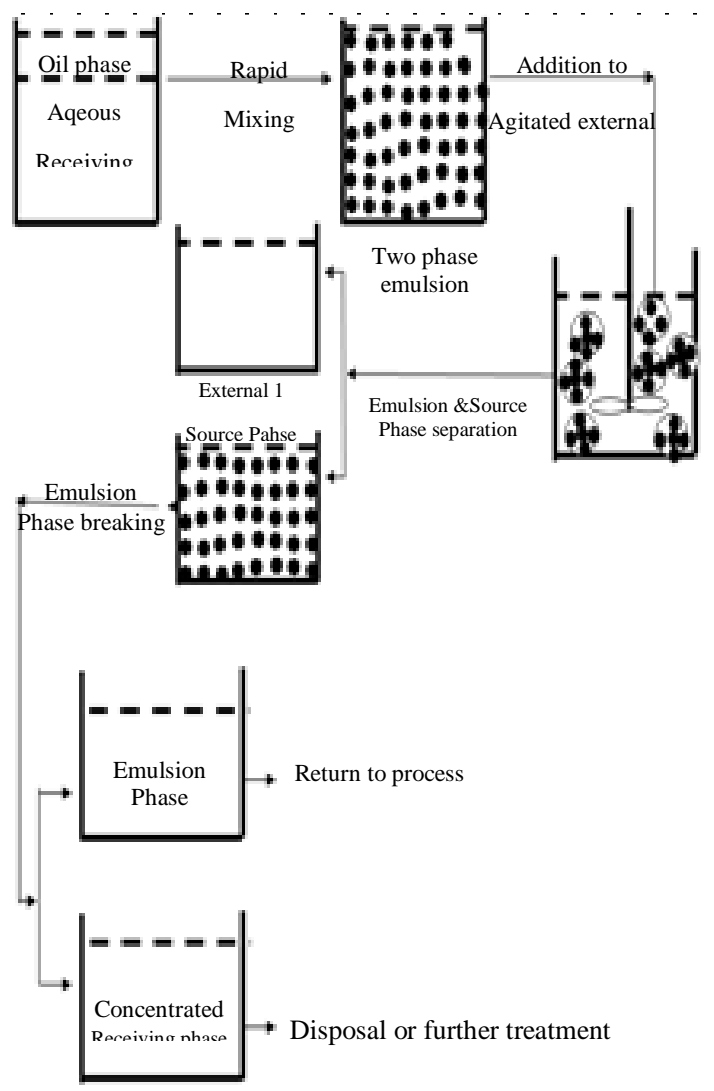

Figure 2 : A Sequence of Events for an (W/ON) Emulsion Liquid Membrane System(Kris Tri Basuki et al, Jurnal Urania, Vol 22 No 3 2016, 133-202) 
The metals are present in the external aqueous phase to be extracted by the extractors that exist in the organic phase by forming complex compounds. Complex compounds is further decomposed by internal water phase, therefore the extraction and re-extraction or stripping occurs simultaneously (19) (Figure 2).

To determine the success of the process can be seen from the efficiency of extraction, stripping efficiency, and total efficiency.

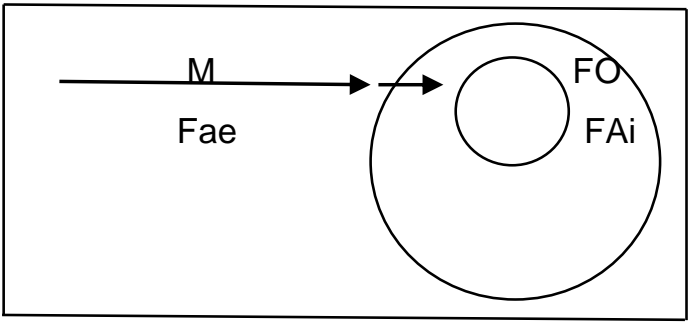

Figure 3 : Metal transfer on the extraction of membrane emulsion (Kris Tri Basuki et al, Jurnal Urania, Vol 22 No 3 2016, 133-202)

$$
\begin{array}{ll}
\mathrm{M} & =\text { Metal } \\
\mathrm{FAe} & =\text { External phase aqueous } \\
\mathrm{FAi} & =\text { Internal phase aqueous } \\
\mathrm{FO} & =\text { Organic phase }
\end{array}
$$

Efficiency calculation formula according to the following equation (19):

$$
\begin{aligned}
& \text { Extraction Ef ficiency }=\frac{(\text { VFAeo.CFAeo })-(\text { VFAe.CFAe }]}{(\text { FAeo CFAeo })} \\
& \times 100 \%
\end{aligned}
$$

Total Efficiency $=\frac{(\text { VFAi. CFAi })}{(\text { VFAeo. CFAeo })} \times 100 \%$
Stripping Efficiency $=\frac{(\text { VFAi. CFAeo })}{(\text { VFAeo, CFAeo })-(\text { VFAe.CFAe })} \times 100 \%$

Where:

VFAeo = The volume of the external aqueous phase before extraction (initial).

VFAe $=$ The volume of the external aqueous phase after extraction

VFAio = The volume of the internal aqueous phase before extraction (initial)

$\mathrm{VFAi}=$ The volume of the internal aqueous phase after extraction

CFAeo = The concentration of the internal aqueous phase before extraction (initial)

CFAe = The concentration of the external aqueous phase after extraction

CFAio = The concentration of the internal aqueous phase before extraction (initial)

CFAi = The concentration of the internal aqueous phase after extraction.

\section{EXPERIMENTAL}

\subsection{Material :}

$\mathrm{ZrO}\left(\mathrm{NO}_{3}\right)_{2}, \mathrm{HfO}\left(\mathrm{NO}_{3}\right)_{2}$ from Merck, $\mathrm{HNO}_{3}, \mathrm{TOPO}$, Kerosene, Span-80.

\subsection{Tools :}

Heating and magnetic stirrer, stirrer ultra Turax, appliance glass and XRF.

\subsection{Ways of working :}

\subsubsection{Making the emulsion membrane} (FM) and internal water phase (Fai)

$10 \mathrm{~mL}$ of $5 \%$ surfactant Span-80 were dissolved in $10 \mathrm{~mL}$ (5\% -Kerosene TOPO) as the organic phase plus $10 \mathrm{~mL}$ 
$\mathrm{H}_{3} \mathrm{PO}_{4} 3 \mathrm{M}$ as an internal phase (FAi). Ultra Turax was stirred for 15 minutes with a stirring speed varies from $2000-10000 \mathrm{rpm}$. The emulsion is formed as membrane phase (FM) is used for extraction of $20 \mathrm{ml}$ the feed solution. The feed or external aqueous phase is $\mathrm{Zr} 10 \mathrm{~g} / \mathrm{L}$ and $\mathrm{Hf} 0,5 \mathrm{gr} / \mathrm{L}$ in a solution of nitric acid was mixed with $20 \mathrm{~mL}$ FM for 10 minutes with stirring extraction at $500 \mathrm{rpm}$.

\subsubsection{The process of extracting and} Stripping

UNH feed solution concentration (FAe) $1000 \mathrm{ppm}$ by volume of $10 \mathrm{~mL}$ plus $\mathrm{FM}=10 \mathrm{~mL}$ stirred for 10 minutes with a speed $500 \mathrm{rpm}$. The mixture was silenced for a moment and then separated with a separating funnel. FAe volume was measured. FM heated briefly, the emulsion will break into $F O$ and $F A i$. FO and FAi separated and measured its volume. FAe and FAi then analyzed by XRF. This work was repeated to study the effects of \% TOPO-kerosene, and then repeated for influence of variations of the internal water phase molarity $\left(\mathrm{M} \mathrm{HNO}_{3}\right)$, the feed molarity ( $\left.\mathrm{M} \mathrm{H}_{3} \mathrm{PO}_{4}\right)$, and the stirring time. Based on the experimental results analysis data calculation is then used to calculate the efficiency of extraction and stripping efficiency $\mathrm{Zr}$ and $\mathrm{Hf}$.

\section{RESULT AND DISCUSSION}

Initial studies were done to study the effect of stirring speed tool wear Ultra Turax on stability of the manufacture of membranes using $5 \%$ Span- 80 . The results can be shown in Table 1.

Table 1. Effect of stirring speed on the membrane stability

\begin{tabular}{ccc}
\hline $\begin{array}{c}\text { Speed } \\
(\text { rpm) }\end{array}$ & $\begin{array}{c}\text { Time early } \\
\text { rupture } \\
\text { (hours) in } \\
\text { normal } \\
\text { Temperature }\end{array}$ & $\begin{array}{c}\text { Time early } \\
\text { rupture with } \\
\text { heating (minute) } \\
\text { in } 60-70^{\circ} \mathrm{C}\end{array}$ \\
\hline 3000 & 25 & 12 \\
4000 & 146 & 11 \\
6000 & 160 & 11 \\
8000 & 210 & 8 \\
10000 & 195 & 15 \\
\hline
\end{tabular}

In the manufacture of emulsion membrane selected stirring speed of $8000 \mathrm{rpm}$, because the membrane was relatively stable and recovered energy efficiency.

\subsection{Influence of percentage of TOPO-} kerosene (Ratio $\mathrm{FM}: \mathrm{FAe}=10 \mathrm{ml}: 10 \mathrm{ml}=$ $1: 1 ; \mathrm{FAi}=3 \mathrm{M} \mathrm{H}_{3} \mathrm{PO}_{4} ; \mathrm{Fae}=1 \mathrm{M} \mathrm{HNO}_{3}$; Stirring speed $=500 \mathrm{rpm}$; time of extraction : 15 minutes)

The membrane emulsion type was water-in-oil emulsion, ie $\mathrm{H}_{3} \mathrm{PO}_{4}$ in TOPOkerosene. This emulsion can be formed due to existing of span-80. The previous studies have investigated the parameters that form the emulsion becomes stable. Relatively stable emulsion in the use of Span-80 as much as $5 \%$ by volume of the emulsion. Emulsion stability can be measured by the 
amount of creaming figures expressed in the following equation:

$$
\begin{array}{cc}
\Delta \text { VFAe } & \Delta \text { VFAi } \\
\hdashline \text { VFAeo } & \Delta \text { VFAio }
\end{array}
$$

$$
\triangle \mathrm{VFAe}=(\mathrm{VFAe}-\mathrm{VFAeo})
$$

$$
\Delta V F A i=(\text { VFAi }- \text { VFAio })
$$

Determination of $\%$ TOPO is important in the mechanism of metal transfer in the internal water phase (FAi), because with increasing \% TOPO, then CFAi of $\mathrm{Zr}$ and $\mathrm{Hf}$ will be growing and the reaction with TOPO metal will be better. To determine the effect of the displacement of $\mathrm{Zr}$ and $\mathrm{Hf}$ to the organic phase can be seen in the binding ability TOPO $\mathrm{Zr}$ and $\mathrm{Hf}$. At first, the uranium is at $F A e$ in complex form solvated with water and nitrates. Due to the TOPO ligand $\mathrm{H}_{2} \mathrm{O}$ through the extraction process will be replaced by TOPO and form a neutral complex in the organic phase. The greater the concentration of TOPO, then the extraction efficiency will be even greater. This suggests that, the more $\mathrm{Zr}$ and $\mathrm{Hf}$ is extracted and form a neutral complex with TOPO on the membrane phase. $\mathrm{Zr}$ and $\mathrm{Hf}$ is extracted, indicating more easily form a complex with TOPO. This can be shown in Tabel 2.

In Table 2 it can be seen that the concentration of TOPO affect the efficiency of $\mathrm{Zr}$ and $\mathrm{Hf}$. The higher the concentration of TOPO will be increased efficiency. On the use of above $4 \%$ to $5 \%$ relative efficiency TOPO has been steady, due to the greater number of complex compounds of $\mathrm{Zr}$ and $\mathrm{Hf}$ with increasing TOPO, while a limited number of $\mathrm{H}_{3} \mathrm{PO}_{4}$ stripping efficiency of $\mathrm{Zr}$

slightly decreased. $\mathrm{H}_{3} \mathrm{PO}_{4}$ ability to react is still quite strong, so the stripping efficiency is relatively small. The effectiveness of the whole process of extraction method of emulsion liquid membrane can be known by looking at Distribution of Coefficient and Separation Factor of $\mathrm{Zr}$ and $\mathrm{Hf}$.

Table 2. Correlation of \% TOPO Kerosen and extraction efficiency

\begin{tabular}{cccc}
\hline $\begin{array}{c}\text { Extraction } \\
\text { Efficiency } \\
(\%)\end{array}$ & \multicolumn{2}{c}{$\begin{array}{c}\text { Extraction Efficiency (EE), Distribution } \\
\text { Coefficien (DC), and Separation Factor } \\
(\mathrm{M})\end{array}$} \\
\cline { 2 - 4 } & Ziconium & Hafnium & SF \\
\hline 1 & $\mathrm{EE}=50$ and & $\mathrm{EE}=25$ and & 3.03 \\
& $\mathrm{DC}=1.00$ & $\mathrm{DC}=0.33$ \\
2 & $\mathrm{EE}=55$ and & $\mathrm{EE}=24$ and & 3.80 \\
& $\mathrm{DC}=1.22$ & $\mathrm{DC}=0.32$ \\
3 & $\mathrm{EE}=65$ and & $\mathrm{EE}=30$ and & 4.33 \\
4 & $\mathrm{DC}=1.86$ & $\mathrm{DC}=0.43$ \\
& $\mathrm{EE}=94$ and & $\mathrm{EE}=32$ and & 33.34 \\
5 & $\mathrm{DC}=15.67$ & $\mathrm{DC}=0.47$ \\
& $\mathrm{EE}=95$ and & $\mathrm{EE}=32$ and & 40.42 \\
& $\mathrm{DC}=19.00$ & $\mathrm{DC}=0.47$ \\
\end{tabular}

Table 3.Correlation of \% TOPO Kerosen and stripping efficiency

\begin{tabular}{cccc}
\hline $\begin{array}{c}\text { Stipping } \\
\text { Efficiency } \\
(\%)\end{array}$ & $\begin{array}{c}\text { Stripping Efficiency (SE), Distribution } \\
\text { Coefficien (DC), and Separation Factor } \\
(\mathrm{SF})\end{array}$ \\
\cline { 2 - 4 } & Ziconium & Hafnium & SF \\
\hline 1 & $\mathrm{SE}=50$ and & $\mathrm{SE}=46$ and & 1.18 \\
& $\mathrm{DC}=1.00$ & $\mathrm{DC}=0.85$ \\
2 & $\mathrm{SE}=52$ and & $\mathrm{SE}=47$ and & 1.22 \\
& $\mathrm{DC}=1.08$ & $\mathrm{DC}=0.89$ \\
3 & $\mathrm{SE}=55$ and & $\mathrm{SE}=48$ and & 1.33 \\
4 & $\mathrm{DC}=1.22$ & $\mathrm{DC}=0.92$ \\
& $\mathrm{SE}=58$ and & $\mathrm{SE}=48$ and & 1.55 \\
5 & $\mathrm{DC}=1.38$ & $\mathrm{DC}=0.89$ & \\
& $\mathrm{SE}=60$ and & $\mathrm{SE}=47$ and & 1.69 \\
& $\mathrm{DC}=1.50$ & $\mathrm{DC}=0.89$ & \\
\hline
\end{tabular}


To obtain good extraction efficiency is measured by the value of the total uranium.

From Tabel 3 it can be seen that the relatively good results in the use of $5 \%$ TOPO.

3.2 Effect of FAi $\left(\mathrm{HNO}_{3}\right)$ molarity (Ratio $\mathrm{FM}: \mathrm{FAe}=10 \mathrm{ml}: 10 \mathrm{ml}=1: 1$, TOPOKerosene $=5 \%, \mathrm{FAe}=\mathrm{HNO}_{3}$, Stirring Speed $=500 \mathrm{rpm}$, Time of Extraction $=15$ minute)

To find out how much $\mathrm{Zr}-\mathrm{Hf}$ transfer to the organic phase it can be seen in Table 4, FAi molarity relationship with the extraction efficiency, it appears that the extraction efficiency will increase with the increase of phosphoric acid to reach a round 2-3 M $\mathrm{HNO}_{3}$, but thereafter declined. The factors that influence are the chemical reactions and changes negative volume emulsion membrane systems. Increasing concentration of $\mathrm{HNO}_{3}$, causes higher osmotic pressure on $\mathrm{FAi}$, so more water coming into the FAi.

Effect of acidity FAi needs to be done to determine the most optimum acidity, to elaborate on the complex uranium into uranium that was concentration in FAi with ion complexes $\mathrm{HNO}_{3}$.TOPO. Table4. Showed that the extraction efficiency rise with increasing of acidity FAi using nitric acid $3 \mathrm{M}$.

Stripping efficiency grows with increasing of rice FAi acidity and relatively steady after molarity above of $3 \mathrm{M}$. With increasing of $\mathrm{HNO}_{3}$ metal-TOPO decomposition reaction will be more perfect, and causing higher osmotic pressure on FAi causing water to pour into FAi. Basically complex compounds $\mathrm{Zr}\left(\mathrm{NO}_{3}\right)_{4}$. 2TOPO and

$\mathrm{Hf}\left(\mathrm{NO}_{3}\right)_{4}$. 2TOPO are very strong.

Table 4. Correlation of the volume of internal aqueous phase after extraction and extraction efficiency

\begin{tabular}{cccc}
\hline $\begin{array}{c}\text { Extraction } \\
\text { Efficiency } \\
(\%)\end{array}$ & \multicolumn{3}{c}{$\begin{array}{c}\text { Extraction Efficiency (EE), } \\
\text { Distribution Coefficien }(\mathrm{DC}) \text {, and } \\
\text { Separation Factor (SF) }\end{array}$} \\
\cline { 2 - 4 } & Ziconium & Hafnium & SF \\
\hline 1 & $\mathrm{EE}=60$ and & $\mathrm{EE}=46$ and & 1.76 \\
& $\mathrm{DC}=1.50$ & $\mathrm{DC}=0.85$ \\
2 & $\mathrm{EE}=80$ and & $\mathrm{EE}=57$ and & 1.33 \\
& $\mathrm{DC}=4.00$ & $\mathrm{DC}=1.33$ \\
3 & $\mathrm{EE}=96$ and & $\mathrm{EE}=58$ and & 17.3 \\
4 & $\mathrm{DC}=24.00$ & $\mathrm{DC}=1.38$ & 9 \\
& $\mathrm{EE}=90$ and & $\mathrm{EE}=58$ and & 6.52 \\
5 & $\mathrm{DC}=9.00$ & $\mathrm{DC}=1.38$ \\
& $\mathrm{EE}=89$ and & $\mathrm{EE}=57$ and & 6.08 \\
& $\mathrm{DC}=8.09$ & $\mathrm{DC}=1.33$ \\
\end{tabular}

Table 5. Correlation of the volume of internal aqueous phase after extraction and stripping efficiency

\begin{tabular}{|c|c|c|c|}
\hline \multirow[t]{2}{*}{$\begin{array}{c}\text { Stripping } \\
\text { Efficiency } \\
\text { (\%) }\end{array}$} & \multicolumn{3}{|c|}{$\begin{array}{c}\text { Stripping Efficiency (SE), Distribution } \\
\text { Coefficien (DC), and Separation } \\
\text { Factor (SF) }\end{array}$} \\
\hline & Ziconium & Hafnium & SF \\
\hline 1 & $\begin{array}{c}\mathrm{SE}=46 \text { and } \\
\mathrm{DC}=0.85\end{array}$ & $\begin{array}{c}\mathrm{SE}=36 \text { and } \\
\mathrm{DC}=0.56\end{array}$ & 1.52 \\
\hline 2 & $\begin{array}{l}\mathrm{SE}=47 \mathrm{and} \\
\mathrm{DC}=0.89\end{array}$ & $\begin{array}{c}\mathrm{SE}=37 \text { and } \\
\mathrm{DC}=0.59\end{array}$ & 1.51 \\
\hline 3 & $\begin{array}{c}\mathrm{SE}=47 \text { and } \\
\mathrm{DC}=0.89\end{array}$ & $\begin{array}{c}\mathrm{SE}=38 \text { and } \\
\mathrm{DC}=0.61\end{array}$ & 1.45 \\
\hline 4 & $\begin{array}{c}\mathrm{SE}=48 \text { and } \\
\mathrm{DC}=0.92\end{array}$ & $\begin{array}{c}\mathrm{SE}=38 \text { and } \\
\mathrm{DC}=0.61\end{array}$ & 1.51 \\
\hline 5 & $\begin{array}{c}\mathrm{SE}=47 \text { and } \\
\mathrm{DC}=0.89\end{array}$ & $\begin{array}{c}\mathrm{SE}=36 \text { and } \\
\mathrm{DC}=0.56\end{array}$ & 1.59 \\
\hline
\end{tabular}

Therefore, when reacted with HNO3.TOPO difficult to unravel. Thus resulting that the stripping of $\mathrm{Zr}-\mathrm{Hf}$ is not too large. 
(Kris)

Effect of molarity $\mathrm{FAi}$ against stripping efficiency can be seen in Table 5, the complex TOPO-HNO3 getting weaker so with the addition of $\mathrm{HNO} 3$ molarity. Because the difference is not so great for the efficiency stripping of the process taken in 3 $\mathrm{M} \mathrm{H} 3 \mathrm{PO} 4$. Merging both extraction efficiency and stripping efficiency will be obtained (Table 4 and Table 5).

3.3 Effect of FAe $\left(\mathrm{H}_{3} \mathrm{PO}_{4}\right)$ Molarity (Ratio $\mathrm{FM}: \mathrm{FAe}=10 \mathrm{ml}: \mathrm{ml}=1: 1$, TOPOKerosene $=5 \%, \mathrm{FAi}=3 \mathrm{M} \mathrm{HNO}_{3}$, stirring speed $=500 \mathrm{rpm}$, Time of Extraction $=15$ Minute).

To find out how much metal transfer to the organic phase it can be seen in Table 6 , the relationship with the FAe acidity extraction efficiency. At first the uranium is at $F A e$ in complex form solvated by water and nitrate. Due to the TOPO through the extraction process, $\mathrm{H}_{2} \mathrm{O}$ ligands will be replaced by TOPO and form a neutral complex in the organic phase.

In Table 6 it appears that at the time the acidity of $3 \mathrm{M}$, the efficiency of extraction started rising and reached a maximum of 1 $M$, but thereafter declined. Affecting factors are chemical reactions and changes negative volume emulsion membrane systems.

Effect of molarity or acidity greatly to the extraction of $\mathrm{Zr} / \mathrm{Hf}$. The increase in the acidity of the extraction system is solvation, especially for extractant TOPO, causing TOPO will react with the acid solvent in this case $\mathrm{H}_{3} \mathrm{PO}_{4}$.

The fall in the efficiency of the extraction on the acidity after $1 \mathrm{M}$, as a result of the reaction between TOPO with H3PO4 as a solvent feed. The factors that cause TOPO at high acidity are not able to extract the maximum $\mathrm{Zr}-\mathrm{Hf}$.

Metal extraction in the extraction system is influenced also by solvation of anions in the water phase. With the increase in acidity is an increase $\mathrm{H} 3 \mathrm{PO} 4$ or ion PO4-3 excess in the solution.

Table 6. Correlation of the volume of external aqueous phase after extraction and extraction efficiency

\begin{tabular}{cccc}
\hline $\begin{array}{c}\text { Extraction } \\
\text { Efficiency }\end{array}$ & \multicolumn{2}{c}{$\begin{array}{c}\text { Extraction Efficiency (EE), Distribution } \\
\text { Coefficien (DC), and Separation Factor (SF) }\end{array}$} \\
\cline { 2 - 4 } Ziconium & Hafnium & SF \\
\hline 1 & EE $=60$ and & EE $=46$ and & 1.76 \\
& $\mathrm{DC}=1.50$ & $\mathrm{DC}=0.85$ \\
2 & $\mathrm{EE}=80$ and & $\mathrm{EE}=57$ and & 1.33 \\
& $\mathrm{DC}=4.00$ & $\mathrm{DC}=1.33$ \\
3 & $\mathrm{EE}=87$ and & $\mathrm{EE}=58$ and & 4.85 \\
4 & $\mathrm{DC}=6.69$ & $\mathrm{DC}=1.38$ \\
& $\mathrm{EE}=90$ and & $\mathrm{EE}=58$ and & 6.52 \\
5 & $\mathrm{DC}=9.00$ & $\mathrm{DC}=1.38$ \\
& $\mathrm{EE}=92$ and & $\mathrm{EE}=57$ and & 8.65 \\
& $\mathrm{DC}=11.50$ & $\mathrm{DC}=1.33$
\end{tabular}

Table 7. Correlation of the volume of external aqueous phase after extraction and stripping efficiency

$\begin{array}{cc}\text { Stripping } & \text { Stripping Efficiency (SE), Distribution } \\ \text { Efficiency } & \text { Coefficien (DC), and Separation Factor }\end{array}$

(\%) (SF)

\begin{tabular}{cccc}
\cline { 2 - 4 } Ziconium & Hafnium & SF \\
\hline \multirow{4}{*}{2} & $\mathrm{SE}=46$ and & $\mathrm{SE}=36$ and & 1.52 \\
& $\mathrm{DC}=0.85$ & $\mathrm{DC}=0.56$ & \\
& $\mathrm{SE}=47$ and & $\mathrm{SE}=37$ and & 1.51 \\
3 & $\mathrm{DC}=0.89$ & $\mathrm{DC}=0.59$ & \\
& $\mathrm{SE}=47$ and & $\mathrm{SE}=38$ and & 1.45 \\
4 & $\mathrm{DC}=0.89$ & $\mathrm{DC}=0.61$ & \\
& $\mathrm{SE}=47$ and & $\mathrm{SE}=38$ and & 1.45 \\
5 & $\mathrm{DC}=0.89$ & $\mathrm{DC}=0.61$ & \\
& $\mathrm{SE}=48$ and & $\mathrm{SE}=36$ and & 1.64 \\
& $\mathrm{DC}=0.92$ & $\mathrm{DC}=0.56$ & \\
\hline
\end{tabular}


The formation of complex compounds $\mathrm{Zr}(\mathrm{NO} 3) 4.2 \mathrm{TOPO}$ and $\mathrm{Hf}(\mathrm{NO} 3) 4.2 \mathrm{TOPO}$, cause is not readily biodegradable at the

time of stripping, so the value could not be higher stripping efficiency. Uranium metal complex that forms in greater number, while the $\mathrm{Zr} / \mathrm{Hf}$-TOPO reduced, so that the efficiency of stripping decrease (Table 7).

\subsection{Effect of Extraction Time (Ratio FM :}

$\mathrm{FAe}=10 \mathrm{~mL}: 10 \mathrm{~mL}=1: 1$, TOPOKerosene $=5 \%, \mathrm{FAi}=3 \mathrm{M} \mathrm{HNO}_{3}$, stirring speed $=500 \mathrm{rpm}, \mathrm{FAe}=5 \mathrm{M} \mathrm{H}_{3} \mathrm{PO}_{4}$ ).

The extraction time is required to allow contact during the process of extraction and stripping lasts until it reaches equilibrium. The extraction process takes place between the reaction of $\mathrm{Zr} / \mathrm{Hf}$ with TOPO. Stirring or extraction will form a new emulsion to emulsion membrane of a different size. Because there will be increase or decrease between the two phases of water, namely FAe and FAi.

With the entry $\mathrm{FAe}$ into $\mathrm{FAi}$ accompanied by the transfer of uranium metal into TOPO as FO and forwarded FAi. U-TOPO extraction process and form a complex compound neutral Metal-TOPO pass through the membrane and decomposed by a stripping agent into the FAi. Decomposition for their ion exchange reaction with $\mathrm{H} 3 \mathrm{PO} 4$ where the complex will release reacting $\mathrm{Zr}(\mathrm{NO} 3) 4$. 2TOPO and $\mathrm{Hf}(\mathrm{NO} 3) 4$. 2TOPO.

The longer time of extraction, the extracted metals to form metal complexTOPO will be more and more. Table 8 and
Table 9 are shown the relationship between the extraction efficiency, and eextraction efficiency increases with the length of time of extraction, the optimum condition is

achieved in 10 minutes, because of its efficiency relatively steady, the complex $\mathrm{Zr}(\mathrm{NO} 3) 4$. 2TOPO and $\mathrm{Hf}(\mathrm{NO} 3) 4.2 \mathrm{TOPO}$. .

Table 8. Correlation of Extraction Time and aqueous phase and Extraction efficiency

\begin{tabular}{cccc}
\hline $\begin{array}{c}\text { Extraction } \\
\text { Time } \\
\text { (Minute) }\end{array}$ & $\begin{array}{c}\text { Extraction Efficiency (EE), Distribution } \\
\text { Coefficien (DC), and Separation }\end{array}$ \\
& \multicolumn{3}{c}{ Factor (SF) } \\
\cline { 2 - 4 } & Ziconium & Hafnium & SF \\
\hline 10 & EE $=94$ and & EE $=56$ and & 12.34 \\
& DC $=15.67$ & $\mathrm{DC}=1.27$ \\
20 & $\mathrm{EE}=95 \mathrm{and}$ & $\mathrm{EE}=57$ and & 14.29 \\
& $\mathrm{DC}=19.00$ & $\mathrm{DC}=1.33$ \\
30 & $\mathrm{EE}=94$ and & $\mathrm{EE}=58$ and & 11.56 \\
40 & $\mathrm{DC}=15.67$ & $\mathrm{DC}=1.38$ \\
& $\mathrm{EE}=94$ and & $\mathrm{EE}=58$ and & 11.56 \\
50 & $\mathrm{DC}=15.67$ & $\mathrm{DC}=1.38$ \\
& $\mathrm{EE}=94$ and & $\mathrm{EE}=57$ and & 11.78 \\
& $\mathrm{DC}=15.67$ & $\mathrm{DC}=1.33$ & \\
\hline
\end{tabular}

Table 9. Correlation of Extraction Time and the aqueous phase Stripping efficiency

\begin{tabular}{|c|c|c|c|}
\hline \multirow[t]{2}{*}{$\begin{array}{l}\text { Strippin } \\
\text { g Time } \\
\text { (Minute) }\end{array}$} & \multicolumn{3}{|c|}{$\begin{array}{c}\text { Stripping Efficiency (SE), Distribution } \\
\text { Coefficien (DC) and Separation Factor } \\
(\mathrm{SF})\end{array}$} \\
\hline & Ziconium & Hafnium & SF \\
\hline 10 & $\begin{array}{c}\mathrm{SE}=47 \text { and } \\
\mathrm{DC}=0.89\end{array}$ & $\begin{array}{c}\mathrm{SE}=38 \text { and } \\
\mathrm{DC}=0.61\end{array}$ & 1.46 \\
\hline 20 & $\begin{array}{c}\mathrm{SE}=47 \text { and } \\
\mathrm{DC}=0.89\end{array}$ & $\begin{array}{c}\mathrm{SE}=37 \text { and } \\
\mathrm{DC}=0.59\end{array}$ & 1.51 \\
\hline 30 & $\begin{array}{c}\mathrm{SE}=46 \text { and } \\
\mathrm{DC}=0.85\end{array}$ & $\begin{array}{c}\mathrm{SE}=36 \text { and } \\
\mathrm{DC}=0.56\end{array}$ & 1.52 \\
\hline 40 & $\begin{array}{c}\mathrm{SE}=47 \text { and } \\
\mathrm{DC}=0,89\end{array}$ & $\begin{array}{c}\mathrm{SE}=38 \text { and } \\
\mathrm{DC}=0.61\end{array}$ & 1.45 \\
\hline 50 & $\begin{array}{c}\mathrm{SE}=48 \text { and } \\
\mathrm{DC}=0.92\end{array}$ & $\begin{array}{c}\mathrm{SE}=36 \text { and } \\
\mathrm{DC}=0.56\end{array}$ & 1.64 \\
\hline
\end{tabular}


In Table 8 and Table 9 are shown that efficiency has been steadily after 10 minutes, because during that time already reached saturation point or achieve equilibrium.

The combined efficiency of extraction and stripping efficiency will generate total efficiency. In total efficiency, obtained by the graph in Figure 15. The total efficiency reaches a maximum at 10 minutes and after that relatively constant. It showed that in 10 minutes $5 \%$ TOPO capabilities have reached a saturation point in extraction of $\mathrm{Zr} / \mathrm{Hf}$ clicking, so although the extraction time plus efficiency will not increase. Relative a good of extraction time at 10 minutes, which means that during time the uranium at feeds extraction by TOPO formed a neutral complex. In that interval $\mathrm{H}_{3} \mathrm{PO}_{4}$ who are at FAi able to download all the decomposition of metal-ligand complexes TOPO formed on the membrane phase during the extraction process. So as much as the amount of $\mathrm{H}_{3} \mathrm{PO}_{4}$ complex $\mathrm{Zr} / \mathrm{Hf}-\mathrm{TOPO}$

\section{CONCLUSION}

The relative good result of this research is the extraction volume of $10 \mathrm{ml}$ feed solution in an atmosphere of $5 \mathrm{M}$ $\mathrm{H}_{3} \mathrm{PO}_{4}$, membrane extraction with $10 \mathrm{ml}$ of $5 \%$ TOPO-kerosene and $\mathrm{HNO}_{3} 3 \mathrm{M}$ for 10 minutes with a stirring speed at the time of extraction of $500 \mathrm{rpm}$, speed manufacture of membranes $8000 \mathrm{rpm}$ and the use of span80 equal the $5 \%$. In this state obtained Separation Factor (SF) of $\mathrm{Zr}$-Hf Is 17.39.

\section{ACKNOWLEDGEMENTS}

The author would like to thank to Mulyono, Bambang EHB, Imam Prayogo, Sudarso and Trimohadi who have helped this work in the laboratory of the Center for Technology Accelerator and process materials.

\section{REFERECE}

1. Susana Tuning S, Tri Handini, Dwi Biyantoro, Samin, Ekstraksi Zr dan Hf menggunakan campuran ekstraktan TBP dan Cyanex 921. Ganendra Journal of Nuclear Science and Technology 2016; 19 (1): $27-35$.

2. Xu Zhi-Gao, Wang Li-Jun, Wu Yan-Ke, Chi Ru-An, Zhang Li, Wu Ming. Solvent Extraction of Hafnium from Thiocyanic Acid Medium In DIBK-TBP Mixed System. Trans. Nonferrous Met. Soc. China 2012; 22: 1760-1765.

3. Zolfonoun. Separation of zirconium and hafnium by solvent extraction using mixture of TBP and Cyanex 923. Journal of Nuclear Materials 2011; 412: 334-337.

4. Branken DJ, Lachman G, Krieg HM, Bruinsma OSL. Influence of KF and HF on the selectivity of $\mathrm{Zr}$ and $\mathrm{Hf}$ Separation by Fractional Crystallization of $\mathrm{K}_{2} \mathrm{Zr}(\mathrm{Hf}) \mathrm{F}_{6}$. Ind. Amp Eng. Chem. Res. 2010; 49: 797-808.

5. Raju Banda, Hwa Young Lee And Man Seung Lee. Separation of $\mathrm{Zr}$ from $\mathrm{Hf}$ in Hydrochloric Acid Solution Using AmineBased Extractants. Ind. Eng. Chem. Res., 2012; 51 (28): 9652-9660. 
6. Raju Banda, Soo Hwan Min And Man Seung Lee. Selective extraction of $\mathrm{Hf}(\mathrm{IV})$ over $\mathrm{Zr}(\mathrm{IV})$ from aqueous $\mathrm{H}_{2} \mathrm{SO}_{4}$ solutions by solvent extraction with acidic organophosphorous based extractants. Journal of Chemical Technology and Biotechnology 2014; 89 (11): 1712-1719.

7. Raju Banda And Man Seung Lee. Solvent Extraction for the Separation of $\mathrm{Zr}$ and $\mathrm{Hf}$ from Aqueous Solutions.

Separation \& Purification Reviews 2015; 44 (3): 199-215.

8. Ling Yun Wang, Hwa Young Lee And Man Seung Lee. Solvent Extraction of Zirconium and Hafnium from Hydrochloric Acid Solutions Using Acidic Organophosphorus Extractants and Their Mixtures with TOPO. Materials Transactions, 2013; 54 (8):1460 to 1466.

9. Kris Tri Basuki, Dwi Biyantoro. Kinetika Reaksi Pemisahan $\mathrm{Zr}$ - Hf Pada Ekstraksi Cair - Cair Dalam Media Asam Nitrat. J. Tek. Bhn. Nukl., 2011; 7 (1): 66 $-73$.

10.Uchikoshi M, Mimura K, Isshiki M. Anionexchange separation of zirconium from hafnium using a multi-column method . TMS Annual Meeting, 2012: 303-314.

11.Endang Susiantini, Moch. Setyadji, Adsorbsi Hafnium (Hf) Dalam Resin Penukar Anion Dowex-1X8. Jurnal IPTEK Nuklir Ganendra 2014; 17(1):1-8.

12.Agata Jakóbik-Kolon, Marek Smolik, Hanna Jaroszek. The influence of the treatment of $\mathrm{Zr}(\mathrm{IV})$ and $\mathrm{Hf}(\mathrm{IV})$ sulfate solution on the ion-exchange purifying of zirconium from hafnium on Diphonix ${ }^{\circledR}$ Resin. Hydrometallurgy 2013;140:77-81.
13.Endang Susiantini, Moch. Setyadji.

Pemisahan Zr-Hf Dalam Asam Sulfat Dengan Resin Penukar Anion. Jurnal Teknologi Bahan Nuklir 2012;8(2):44- 55. 14.Moch. Setyadji, Endang Susiantini. Pemodelan Pemisahan Zirkonium Dan Hafnium Menggunakan Kromatografi Anular. Jurnal Pengembangan Energi Nuklir 2014; 16 (1): 23 - 29.

15.Delons L, Lagarde S, Favre-Reguillon A, Pellet-Rostaing S, Lemaire M, Poriel L. Process for the separation and purification of hafnium and zirconium . US Patent number: 2010, 770, 896, 204. 16. Monnahela OS, Augustyn WG, Nel JT, Pretorius CJ, Wagener JB. The Vacuum Sublimation Separation of Zirconium and Hafnium Tetrafluoride. PMDN Conference, 2013, Cape Town.

17.Shin JH, Choi MS, Min DJ, Park JH Isothermal and non-isothermal sublimation kinetics of zirconium tetrachloride $\left(\mathrm{ZrCl}_{4}\right)$ for producing nuclear grade Zr. Mater. Chem. Phys. 2014; 143: 1075-1084.

18. Pretorius CJ, Pienaar AD, Crouse PL, And Niemand HF. Sublimation Kinetics of Zirconium Tetrafluoride. Advanced Materials Research, 2014; 1019: 398-405.

19. Kris Tri Basuki, Nurimaniwathy, Dian Puspita, Bambang E.H.B.. Use of Membrane Emulsion Span 80 and TOPO in Uranium Extraction and Stripping Jurnal IImiah Daur Bahan Bakar Nuklir URANIA 2016; 22 (3). Pusat Teknologi Bahan Bakar Nuklir, BATAN.

20.Brecevic L. And Kralj D. Precipitation of Some Slightly Soluble Salts Using 
Emulsion Liquid Membranes. CCACAA, 2008; 4: 1049 -1060.

21.Hartmann D., Extraction De L'Uranium Des Solution, delixivation, en tas Par des Membrane Liquid Emulsionnnes, These, Ecole Centrale Paris, 2009, Paris.

22. Hirai., Nishihihama, S., and Komasawa,

I., Mechanism of photoreductive stripping of iron (III) in a Liquid-Liquid Extraction System and Its Application for Hydrometalllurgical Prcocess, Ind. Eng. Chem. Res., 2009; 38: 4850 - 4856.

23.Jing-Qing S, Wei-Ping Y, Yong-Xin Z, and Li-Jun Y. Extraction of Alanine Using Emulsion Liquid Membranes Featuring a cationic Carrier , J. Membranes Sci. 2006; 120: 45 - 53.

24.Jyh-Herng C, Yin-Yun K., and Chia-Hung, L., Selective Separation of Vanadium from Molibdenum Using $D_{2} E H P A-$ Immobilized Amberlite XAD-4 Resin , Sep. Sci. Technol 2013; 38: 3827 - 3852.

25.Dhadke PM And Singh R K. Extraction and separation of titanium (IV) with $D_{2}$ EHPA and PC-88A from aqueous perchloric acid solution ., J. Serb. Che. Soc. 2012; 67: 507 - 521.

26. Casnaval D, Oniscu C, and Galaction A I. Study on Reactive Extraction of Erychromycin , Roum. Biotechnol. Lett., 2010; 5: 439 - 447.

27. Casamata G, Chavarie, and Angelino H. Permeation Rate of Hydrocarbons through Water Membranes in an O/W/O Emulsion Sytem.AIChE.2008;24:945-956.
28.Korfan S, Shino O, Wahaud A, and Dahdouh A. 2010. Stripping of Uranium From $\mathrm{D}_{2}$ EHPA/TOPO Solvent By Ammonium Carbonat Solutions. Chem. Eng., 2010; 44: 123 - 132.

29.Nakano K., Kato S., Noritomi H, And Nagahama K.. Extraction of Eicosapentaenoic Acid Ethyl Ester from Model Media Using Ag(I)-containing O/W/O-Type Emulsion Liquid Membranes. J. Membranes Sci., 2007; 136: $127-139$.

30.Sun D, Duan X, Li W, and Zhou D.

Demulsification of Water-in-oil emulsion by Using Porous Glass Membrane. J. Membrane Sci. 2008; 146: 65 - 72.

31.Wang C, Liu D, and Zhang J. Solvent Extraction of Indium (III) and Iron (III) from Sulfuric Acid Media by Mixtures of D2EHPA and Cyanex 92 , Sep. Purif. Technol 2011; 61: 75 - 89.

32.Wang C, Liu D, and Zhang J. Solvent Extraction of Indium (III) and Iron (III) from Sulfuric Acid Media by Mixtures of D2EHPA and Cyanex 92 , Sep. Purif. Technol 2011; 61: $75-84$. 
Jurnal Sains dan Teknologi Nuklir Indonesia

ISSN $1411-3481$

Indonesian Journal of Nuclear Science and Technology

EISSN 2503 - 1287

Vol. 18, No 1, Februari 2017; 25 - 38 